\title{
Effect of Lockdown,Temperature, and Humidity on the Pattern of COVID-19 in Erbil Province,Kurdistan Region, Iraq
} Rundk Hwaiz $(\mathrm{PhD})^{1}$, Katan Ali $(\mathrm{PhD})^{2}$ and Namir Al-Tawil $(\mathrm{PhD})^{3}$

${ }^{1}$ College of Health Sciences, Hawler Medical University, Erbil ,Iraq

${ }^{2}$ College of Health Sciences, Hawler Medical University, Erbil ,Iraq

${ }^{3}$ College of Medicine, Hawler Medical University, Erbil ,Iraq

Correspondence Address:

Dr. Rundk Hwaiz

College of Health Sciences, Hawler Medical University , Erbil ,Iraq

email: rundk.hwaiz@hmu.edu.krd

Received: 23 November 2020

Revised: 15 December 2020

Accepted: 10 January 2021

Published: 25 June 2021

Diyala Medical Journal 2021:20(2): 56- 67

\section{Abstract}

Background: COVID-19 was first reported in Erbil province in Iraq on March 19, 2020. The effect of lockdown on reducing the spread of the novel coronavirus and the effect of weather conditions (air temperature and humidity) on the daily reported number of cases and death rate of COVID-19 were investigated during April to July, 2020.

Objective: To investigate the effect of lock down on reducing the spread of the novel coronavirus pandemic and the effect of weather conditions (air temperature and humidity) on the daily reported number of cases and death rate of COVID-19.

Patients and Methods: The data collected during three different periods, the first (total lockdown), followed by the second period of lockdown relaxation, which was followed by the third period (interrupted relaxation of lockdown) that reported hundreds of new cases daily. The real-time PCR assay was performed on suspected COVID-19 patients according to the protocol established by the World Health Organization.

Results: Temperature and relative humidity were recorded in Erbil city in Iraq. Patients' age ranged (2-70) years old. Out of (1469) patients confirmed positive with COVID-19, 57.7\% of them were males, $31.3 \%$ were females, and the rest $(11 \%)$ were children. The mean number of patients per day was 32.77 during the period of interrupted relaxation lockdown which was significantly higher than in the total-lock down period (3.88 patient), and the relaxation lockdown period (1.93 patient). The mortality rate per day was 0.77 during the period of interrupted relaxation lockdown was significantly higher than the rates $(0.0 \%)$ of the other periods. Moreover, increasing the temperature increased the number of confirmed cases in July while, low relative humidity significantly increased the rate of reported cases. 
Conclusion: The increase in the number of reported cases of COVID-19, might be related to the interruption of lockdown. Moreover, the daily reported cases and mortality rates increased by increasing the temperature from April to June.

Keywords: COVID-19, humidity, temperature, pandemics, Kurdistan region, Iraq

\section{Introduction}

Coronavirus disease 2019 (COVID-19), caused by SARS-CoV-2, at the first appeared in a group of patients suffering from pneumonia of unknown causes in the Hubei province of China, and afterward spreads via global travel to many other countries in the world [1]. Due to the emerging as a third highly pathogenic disease that rises in the last 20 years, on eleventh February, 2020. The International Committee on Taxonomy of Viruses has named the virus into severe acute respiratory syndrome coronavirus 2 (SARS-CoV-2) .On March $11^{\text {th }}, 2020$ the disease was considered by the WHO as a pandemic [2].

Countries put stringent measures in place, sometimes called lockdowns, in response to the intense transmission. Many have used the time to ramp up their ability to test, trace, isolate and care for patients, which is the best way to track the virus, slow the spread and take pressure off the health systems. However, such strong measures have come at a cost and we recognize the serious socioeconomic impact of the lockdowns, which have had a detrimental effect on many people's lives.To date thereis no specific effective vaccine, and specific treatment, however, the protection and control measure are the best ways for prevention of its transmission, [3].

There are several factors, contribute in transmission of viruses, such as environmental conditions (including temperature and humidity), the quality of medical care and the density of population [4].

Many infectious diseases show a seasonal pattern in their incidence. An onerous burden for health care systems around the globe, including human coronaviruses (HCoV229E, HCoV-HKU1, HCoV-NL63, and HCoV-OC43), which usually cause to mild respiratory symptoms, which are more active in the winter season [1]. The mechanism related to these patterns of weather estimation that lead to possible transmission and infection is due to the ability of the virus to maintain in external environmental conditions before getting into a host [5]. It has been reported that rising in temperature and adequate humidity, significant inactivate coronaviruses while cold and dry weather mediate the virus for long time survival on different types of surfaces and facilitate its transmission [6].Therefore, understanding the relationship between weather and the transmission of COVID-19 is key to forecast the intensity and end time of this epidemic.

The aims of this study were investigating the effect of lock down on reducing the spread of the novel coronavirus pandemic and the effect of weather conditions (air temperature and humidity) on the daily reported number of cases and death rate of COVID-19. 


\section{Patients and Methods}

The study analyzed the daily number of reported cases, the death rate of the coronavirus disease (COVID-19) in Erbil city in Iraq from the $1^{\text {st }}$ of April to the $3^{\text {rd }}$ of July 2020. The data was obtained from the Erbil public hospitals records, knowing that during the study period, every positive patient (according to PCR) was admitted to the hospital irrespective of symptoms. Age and gender of patients were also obtained. The effect of lockdown control measures and weather parameters (temperature and humidity) have been studied too. Confirmation of the diagnosis was done by molecular technique real time PCR. The study was conducted during three different periods. The first one (total lockdown), at the start of the epidemic in Erbil, followed by the second period of lockdown relaxation, which was followed by the third period (interrupted relaxation of lockdown) that reported hundreds of new cases daily. Weather parameters (temperature and relative humidity) have been recorded from the website: (timeanddate.com). The study was approved by the Ethics Committee of Health Sciences College, Hawler Medical University. A questionnaire designed by the researchers was used to collect the personal data of patients.

\section{Statistical analysis}

The Statistical Package for Social Sciences (SPSS) version 25, was used for data entry and analysis. Numerical variables were presented in the form of means and standard deviations (SDs), while categorical variables were summarized and presented by calculating the proportions. One way analysis of variance (ANOVA) was performed to compare the means of three groups, and a post hoc test (LSD) was used to compare every two groups. Pearson correlation coefficient (r) was used to assess the strength of correlation between two numerical variables. Multiple regression was used where the dependent variable was the number of patients. A $\mathrm{P}$ value of $\leq 0.05$ was considered to be statistically significant.

\section{Results}

The total number of patients who have been admitted to hospitals specialized for the novel coronavirus was 1469 . Their mean age $( \pm$ SD) was $39.77 \pm 17.16$ years, the median was 41 years. The age range was 2-77 years. Table 1 shows that the highest proportion of the patients (21.9\%) was aged 40-49 years, while those below 20 years were less affected. More than half $(57.7 \%)$ of the sample were males, $31.3 \%$ were females, and the rest $(11 \%)$ were children (unknown gender because the data was not available). 
Table (1): Age and gender distribution of patients

\begin{tabular}{||l||c||c||}
\hline \multicolumn{1}{||}{} & No. & (\%) \\
\hline \hline Age (years) & & $(6.5)$ \\
\hline \hline 10 & 95 & $(6.9)$ \\
\hline \hline $20-29$ & 102 & $(15.3)$ \\
\hline \hline $30-39$ & 225 & $(17.7)$ \\
\hline $40-49$ & 260 & $(21.9)$ \\
\hline \hline $50-59$ & 321 & $(17.3)$ \\
\hline \hline 60 & 254 & $(14.4)$ \\
\hline \hline Mean $( \pm$ SD) & 212 & $( \pm 17.16)$ \\
\hline \hline Gender & 39.77 & $(57.7)$ \\
\hline \hline Male & & $(31.3)$ \\
\hline \hline Female & 448 & $(11.0)$ \\
\hline *Child (Unknown gender) & 161 & $(100.0)$ \\
\hline \hline Total & 1469 & \\
\hline *hild(Unknown gender)sex of children is not available in the records
\end{tabular}

*child(Unknown gender)sex of children is not available in the records

It is evident in Figure (1) that the number of period of lockdown (interrupted relaxation daily cases started to increase during the third lockdown).

\section{No. of cases/day}

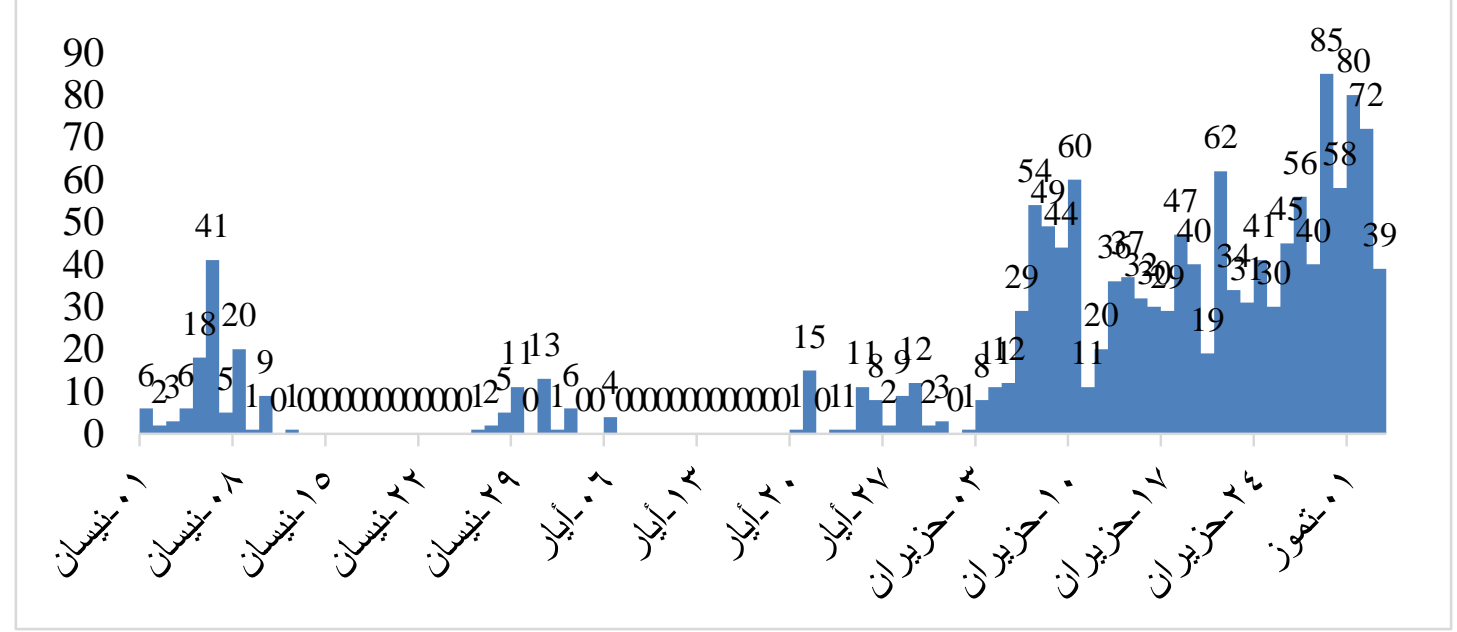

Figure(1): Number of daily cases by time

Note: The period of total lockdown extended from the $1^{\text {st }}$ of April through the $10^{\text {th }}$ of May. The period of relaxation lockdown extended from the $11^{\text {th }}$ of May through the $25^{\text {th }}$ of May. The period of interrupted relaxation lockdown extended from the $26^{\text {th }}$ of May to the $3^{\text {rd }}$ of July.The mean number of patients per day was 32.77 during the period of interrupted relaxation lockdown which was significantly $(\mathrm{P}<0.001)$ higher than that of the total lockdown period (3.88 patient), and also significantly $(\mathrm{P}<0.001)$ higher than that of the relaxation lockdown period (1.93 patient).

None of the patients died during the period of total lockdown, and during the period of 
relaxation lockdown, but it is evident in relaxation lockdown which was significantly Table (2) that the mean number of deaths per higher than the rates $(0.0 \%)$ of the other day was 0.77 during the period of interrupted periods.

Table (2): Means of number of patients and number of deaths by periods of lockdown

\begin{tabular}{|c|c|c|c|c|c|c|c|}
\hline & Period & $\begin{array}{c}\mathbf{N} \\
\text { (days) }\end{array}$ & Mean & SD & $\begin{array}{c}\text { p } \\
(\mathbf{A N O V A})\end{array}$ & $\begin{array}{c}\text { LSD } \\
\text { groups }\end{array}$ & $\bar{p}$ (LSD) \\
\hline \multirow[t]{4}{*}{$\begin{array}{l}\text { No. of } \\
\text { patients }\end{array}$} & $\begin{array}{l}\text { A) Total } \\
\text { lockdown }\end{array}$ & 40 & 3.88 & 7.796 & & A X B & 0.683 \\
\hline & $\begin{array}{l}\text { B) Relaxation } \\
\text { lockdown }\end{array}$ & 15 & 1.93 & 4.574 & & $\mathrm{AXC}$ & $<0.001$ \\
\hline & $\begin{array}{l}\text { C) Interrupted } \\
\text { relaxation } \\
\text { lockdown }\end{array}$ & 39 & 32.77 & 22.693 & $<0.001$ & B X C & $<0.001$ \\
\hline & Total & 94 & 15.55 & 21.259 & & & \\
\hline \multirow[t]{4}{*}{$\begin{array}{l}\text { No. of } \\
\text { deaths }\end{array}$} & $\begin{array}{l}\text { A) Total } \\
\text { lockdown }\end{array}$ & 40 & 0.00 & $\begin{array}{c}<0.001 \\
\end{array}$ & & A X B & $>0.999$ \\
\hline & $\begin{array}{l}\text { B) Relaxation } \\
\text { lockdown }\end{array}$ & 15 & 0.00 & $<0.001$ & & A X C & 0.001 \\
\hline & $\begin{array}{l}\text { C) Interrupted } \\
\text { relaxation } \\
\text { lockdown }\end{array}$ & 39 & 0.77 & 1.495 & 0.001 & B X C & 0.010 \\
\hline & Total & 94 & 0.32 & 1.029 & & & \\
\hline
\end{tabular}

It is evident in Table (3) and Figure (2) that there was a positive significant correlation between the number of patients per day and the temperature, whether the high temperature $(\mathrm{r}=0.593, \mathrm{P}<0.001)$ or the low temperature $(\mathrm{r}=0.441, \mathrm{P}<0.001)$, while there was a negative significant correlation

Table (3): Correlation between number of patients and number of deaths with the environmental temperature and humidity

\begin{tabular}{|c|c|c|c|c|}
\hline & \multicolumn{2}{|c|}{ No. of patients } & \multicolumn{2}{|c|}{ Deaths } \\
\hline & $\mathbf{r}$ & $\mathbf{P}$ & $\mathbf{r}$ & $\mathbf{P}$ \\
\hline High Temp. ${ }^{\circ} \mathrm{C}$ & 0.593 & $<0.001$ & 0.328 & 0.001 \\
\hline Low Temp. ${ }^{\circ} \mathrm{C}$ & 0.441 & $<0.001$ & 0.251 & 0.015 \\
\hline Mean humidity & -0.540 & $<0.001$ & -0.266 & 0.009 \\
\hline
\end{tabular}

Table (4) shows that there was positive significant correlation between the number of $\mathrm{P}=0.008)$; also, with the period of relaxation patients and the high temperature $(\mathrm{B}=1.61$, between the number of patients and the humidity $(\mathrm{r}=-0.540, \mathrm{P}<0.001)$. Regarding the number of deaths per day, the same pattern can be observed, and all the correlations were significant, but the strength of the correlation was less. 


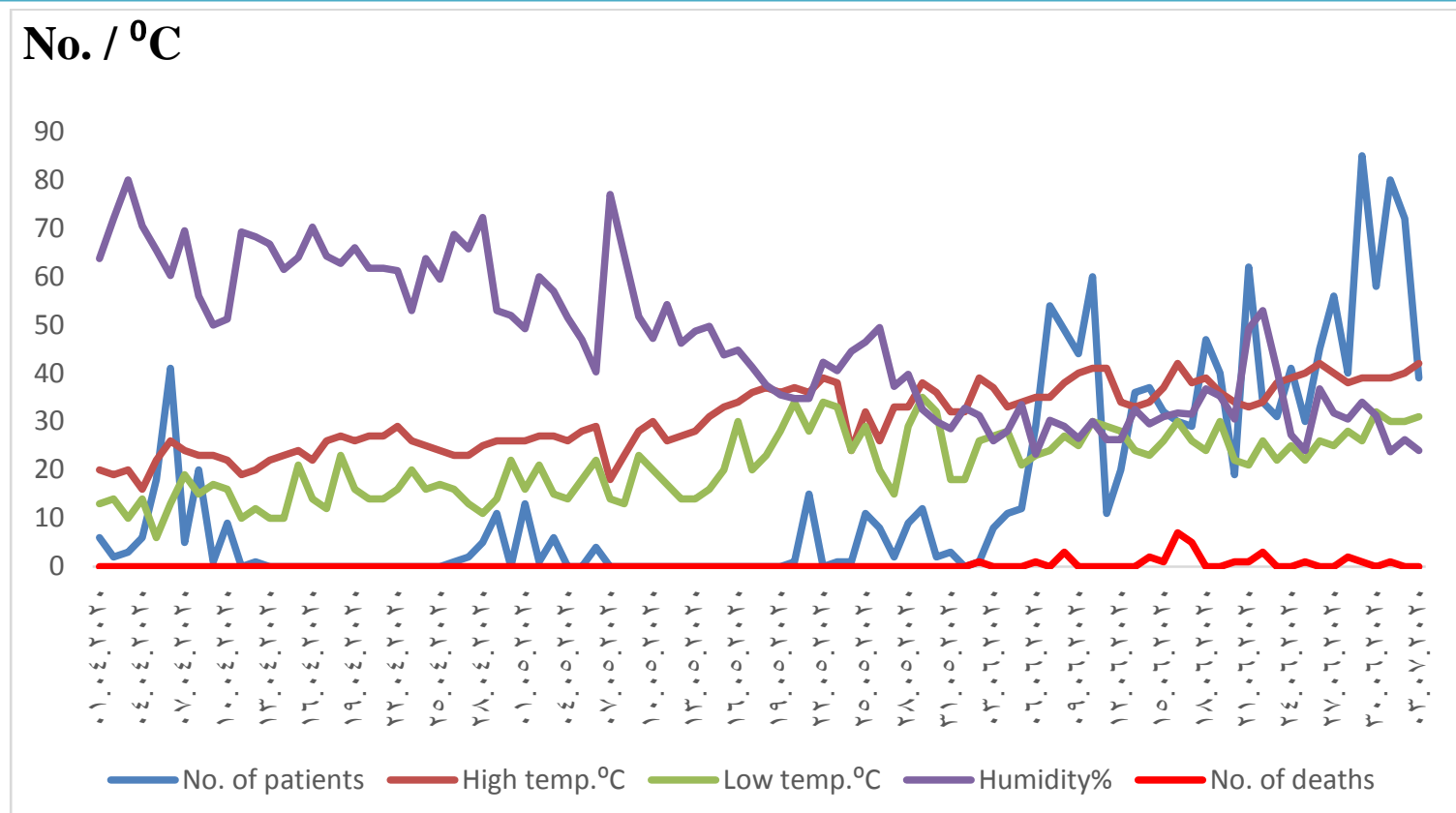

Figure (2): Correlation between number of patients, number of deaths, temperature, and humidity

Table (4): SPSS output of multiple regression analysis where the dependent variable is the number of patients

\begin{tabular}{|c|c|c|c|c|c|c|c|}
\hline & \multicolumn{2}{|c|}{$\begin{array}{l}\text { Unstandardized } \\
\text { Coefficients }\end{array}$} & \multirow{2}{*}{$\begin{array}{c}\begin{array}{l}\text { Standardized } \\
\text { Coefficients }\end{array} \\
\text { Beta }\end{array}$} & \multirow[b]{2}{*}{$\bar{t}$} & \multirow[b]{2}{*}{$\bar{p}$} & \multicolumn{2}{|c|}{$\begin{array}{l}\text { 95.0\% Confidence } \\
\text { Interval for B }\end{array}$} \\
\hline & B & $\begin{array}{c}\text { Std. } \\
\text { Error }\end{array}$ & & & & $\begin{array}{l}\text { Lower } \\
\text { Bound }\end{array}$ & $\begin{array}{l}\text { Upper } \\
\text { Bound }\end{array}$ \\
\hline (Constant) & $\begin{array}{c}-50.292 \\
\end{array}$ & 25.489 & & $\begin{array}{l}-1.973 \\
\end{array}$ & 0.052 & $2-100.947$ & 0.362 \\
\hline $\begin{array}{l}\text { High Temp. } \\
{ }^{\circ} \mathbf{C}\end{array}$ & 1.619 & 0.599 & 0.524 & 2.702 & 0.008 & 0.428 & 2.809 \\
\hline $\begin{array}{l}\text { Low Temp. } \\
{ }^{\circ} \mathrm{C}\end{array}$ & -0.135 & 0.418 & -0.044 & -0.323 & 0.747 & -0.966 & 0.696 \\
\hline $\begin{array}{l}\text { Mean } \\
\text { humidity }\end{array}$ & 0.279 & 0.257 & 0.203 & 1.087 & 0.280 & "-0.232 & 0.790 \\
\hline $\begin{array}{l}\text { Interrupted } \\
\text { relaxation }\end{array}$ & -9.812 & 6.319 & 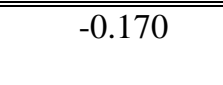 & -1.553 & 0.124 & 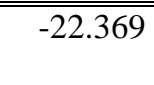 & 2.746 \\
\hline $\begin{array}{l}\text { Relaxation } \\
\text { lockdown }\end{array}$ & 18.104 & 7.379 & 0.422 & 2.453 & 0.016 & 3.440 & 32.768 \\
\hline
\end{tabular}

\section{Discussion}

The mean age $( \pm \mathrm{SD})$ was $39.77 \pm 17.16$ years, the median was 41 years. The proportion of males $(57.7 \%)$ was nearly double the proportion of females $(31.3 \%)$, and the children constituted $11 \%$ (unknown gender because the data were not available). A Chinese study, on COVID-19 patients, found that the median age was 49 years and $73 \%$ were males [7]. Another study reported, that the children aged 10 years and less accounted for just $1 \%$ of all COVID-19 cases [8]. Another study, suggested that SARS$\mathrm{CoV}-2$ infection in adults is more frequent and severe than in children :this is could be related to deference in expression of adults 
ACE2 receptor [9]. Another study reported that the median age of the patients was 56 years, with approximately equal proportions of males and females [10]. While others reported that more than half of the incidences were male and the proportion of them ranged from $51.4 \%$ to $73.2 \%$ [11]. It has been concluded that no age is exempted from this viral infection, as it was reported even in a one-month-old infant [12]. In addition, a study observed that $77.8 \%$ of the patients are between $30-69$ years old and $51.4 \%$ are male [13]. According to another study, the higher mortality rate of COVID-19 cases among the elderly people is related to presence of co morbidities, a weak immune and respiratory system [14].

In this study the males were more than females, and this could be due to the fact that males are more exposed to the environment and they work outside their homes, while a considerable proportion of the women in Erbil are housewives. In addition to that smoking is expected to be more common among males, which may contribute to the higher number of male patients [15].

This study showed a marked increase in the number of cases and deaths during the period of interrupted relaxation lockdown. This could be attributed to opening the borders between the Iraqi cities. The problem is that asymptomatic persons can transmit the disease especially when there is overcrowding, knowing that this period preceded the Muslim's EID, and usually people go to the markets and malls, and many go to mosques to pray where there is overcrowding.

In consistent to our results, a study reported that if these control measure are lifted completely, while there are still high percentage of the population are at risk to keep the (R0) more than one the number of infections would increase, in line with increased contacts basically, interferences are lifted slowly, to avoid a significant increase in infection, in regard to logistical and practical reasons. Another study [16]reported that the lockdown measures may have averted 3.1 million deaths from COVID-19 across

[11] European countries, including 470000 in the UK, however, the researchers warn that European countries are very far from achieving herd immunity, as less than $4 \%$ of their populations were infected with SARS-CoV-2 up to the 4th of May, when lockdowns started to be lifted. A study done in Wuhan, the origin of the COVID 19, focused on the effects of relaxation of lockdown. The study reported that the gradually lockdown relaxation in March, a second wave of cases might occur in the mid-summer. Therefore, the alternative strategies should be taken after relaxation, such as the use of face masks, temperature checks, and social distance, are now needed [17, 18].

The correlation between the numbers of deaths with the numbers of daily cases in our study coincides with the results of a previous study that reported the absolute values of the mortality may differ, even with limited testing; the information on the number of cases can be directly related to the deaths rate caused by SARS-CoV-2. For instance, in the countries (AUS) $1.7 \%$ and(ITA) $14.3 \%$, with a world average of $8.4 \%$. indicating that in countries with a high mortality rate have a higher rate of unrecorded cases [2]. 
It has been estimated that the reproduction number (R0) in (Beijing, Shanghai, Shenzhen, Wenzhou, and the ten Chinese provinces outside Hubei) on Jan 23 has become lower than 1 after the implementation of non-pharmaceutical control measures were applied [19]. On the other hand, premature relaxation of interventions, may lead to transmissibility exceeding 1 again - i.e, the second wave of infections. The $\mathrm{R} 0$ reproductive number is the average number of new cases that result from a single infected person in a whole exposed population [20]. The R0 value can be changed vary by some factors that affect the contact rate among population, like physical distancing and lockdowns strategies in order to decrease the R0 under 1 [21].

According to another study, an initial evaluation of COVID-19 transmission dynamics showed that the R0 of COVID-19 is estimated to be1.4-3.9 [12]. Depending on control measures and other factors, cases may come in waves of different heights (with high waves signaling major impact) and in different intervals. Between $2^{\text {nd }}$ and $29^{\text {th }}$ March European countries applied nonpharmaceutical interventions to control the COVID-19 epidemic including social distancing, prohibit large gatherings, closing schools, and stopping all unessential travel. Accordingly, the study indicated that the "Lockdown has had a really dramatic effect on reducing the rate of transmission, and without it there would have been many more deaths from COVID-19" The US researchers found that without anti-contagion policies in place, the early rates of SARS-CoV-2 daily infection increased rapidly up to $68 \%$ in Iran [4].
Erbil is the city located in north of Iraq. Over the course of the year, the period of summer season starts from, ( June $3^{\text {th }}$ to September $16^{\text {th }}$ ) with an average daily temperature upto $36.11^{\circ} \mathrm{C}$ while, the winter season starts from (November $24^{\text {th }}$ to March $13^{\text {rd }}$ ) with an average daily temperature under $17.77^{\circ} \mathrm{C}$. Moreover, the level of humidity mostly stay constant $0 \%$ throughout year does not vary significantly over the course of the year, remaining a virtually constant $0 \%$ throughout. However, raising the temperature in the hot months did not decrease the -transmission of coronavirus while, the number of positive cases raised quickly in the middle of May with relaxation of lockdown, as presented in Table (3) and Figure (2).

In order to understand whether high temperature reduces the transmission of a novel coronavirus, the daily number of reported cases and the mortality rate in relation to the weather condition were analyzed. We observed that these parameters increased with rising temperature and with decreasing relative humidity. A similar finding was reported from an Iranian study, which reported that the increasing temperature has no influence on the R0 and the transmission of COVID-19 in Bushehr, Iran. In agreement with our results, another study, found that $y$ that the number of COVID-19 cases would not be reduced in a warmer temperature. Moreover, revealed a direct relationship between temperature and COVID-19 cases in which a $1{ }^{\circ} \mathrm{C}$ rise in the mean temperature lead to a $4.9 \%$ increase in the daily reported cases [22]. Unlike humans, bats are constantly flying and exercising, in order to compensate for the 
constant release of energy, bats regularly increase their body temperature to between $\left(38^{\circ} \mathrm{C}\right.$ and $\left.41^{\circ} \mathrm{C}\right)$. As a result, pathogens inside bats evolve to withstand warmer conditions and are able to resist fevers and continue to proliferate when transmitted to humans [23].

On the other hand, it has been reported that the mechanism underlying these weather conditions is related to the capability of the virus to maintain in external environmental conditions before getting into a suitable host. The virus can survive for up to 5 days at temperatures between $11-25^{\circ} \mathrm{C}$ and relative humidity between $40-50 \%$. The virus is also sensitive to humidity, it is expected that the humidity in the air affect the transmissibility of respiratory viruses, once the pathogens have been expelled from the respiratory tract by sneezing, they literally float in the air and they do so far longer period when the humidity is greater [24].

In contrast to our results, a study observed no relations between the daily temperature , the relative humidity and $\mathrm{R} 0$ value. The temperature has a less effective than relative humidity, due to a larger daily variation in relative humidity in compare to the temperature [25]. It has been found that, in winter under dry cool environmental conditions, with low humidity helps viral aerosols maintain for a longer period in air because of their small sizes, which facilitating the spread of the virus. However in warm rainy season regions, the virus via large aerosol particles easily spread, in the relatively-low temperature and nearsaturation humidity [26].They also showed that the rate of incidence of the novel coronavirus was indirectly related to humidity. Another study performed in Hong Kong between11 March and 22 May 2003 showed that as temperature increased from $15^{\circ} \mathrm{C}$ up to $29^{\circ} \mathrm{C}$, SARS-CoV-2 incidences sharply decreased, until they completely disappeared. Moreover, they thought that if the temperature increase up to $30^{\circ} \mathrm{C}$, because the transmission of virus survival will be reduced but, the virus will be absolutely eliminated. It has also been revealed a negative association between COVID-19 case mortality and temperature, as they investigated that the fatility of respiratory diseases significantly increased with reducing the temperature $[2,22]$. Finally, it has been estimated that activity of the virus decrease in higher temperatures and higher relative humidity $\left(38^{\circ} \mathrm{C}\right.$ and $\left.95 \%\right)$ respectively [27].

\section{Conclusions}

Our result concluded that the interruption of lockdown has an obvious effect an increase in the number of COVID-19 cases. Moreover, the temperature variation increased in the daily reported cases and death rates from April to June in our region.

\section{Recommendations}

Owing to the wide spread of the virus in our community, low level of herd immunity and limited health care quality, therefore, control measures such as social distancing, quarantine of contacts, hand washing, and using face masks are highly recommended to reduce the number of cases and hence the mortalities.More comprehensive studies are needed to study the effect of the environmental parameters on the spread of the novel virus. 
Source of funding: The authors received no specific funding for this work.

Ethical clearance: The study was approved by the Ethics Committee of Health Sciences College, Hawler Medical University.

Conflict of interest: The authors declare no conflicts of interest.

\section{References}

[1] Sajadi MM, Habibzadeh P, Vintzileos A, Shokouhi S, Miralles-Wilhelm F, Amoroso A. Temperature, Humidity, and Latitude Analysis to Estimate Potential Spread and Seasonality of Coronavirus Disease 2019 (COVID-19). JAMA network open. 2020;3(6):e2011834. PubMed PMID: 32525550. Pubmed Central PMCID: 7290414.

[2] Ma Y, Zhao Y, Liu J, He X, Wang B, Fu $\mathrm{S}$, et al. Effects of temperature variation and humidity on the death of COVID-19 in Wuhan, China. The Science of the total environment. 2020 Jul 1;724:138226. PubMed PMID: 32408453. Pubmed Central PMCID: 7142681.

[3] Harmooshi NN, Shirbandi K, Rahim F. Environmental concern regarding the effect of humidity and temperature on 2019-nCoV survival: fact or fiction. Environmental science and pollution research international. 2020;27(29):36027-36. PubMed PMID: 32592048. Pubmed Central PMCID: 7316637.

[4]Ahmadi M, Sharifi A, Dorosti S, Jafarzadeh Ghoushchi S, Ghanbari N. Investigation of effective climatology parameters on COVID-19 outbreak in Iran. The Science of the total environment. 2020 Aug 10;729:138705. PubMed PMID:
32361432. Pubmed Central PMCID: 7162759.

[5] Fares A. Factors influencing the seasonal patterns of infectious diseases. International journal of preventive medicine. 2013 Feb;4(2):128-32. PubMed PMID: 23543865. Pubmed Central PMCID: 3604842.

[6] Chan KH, Peiris JS, Lam SY, Poon LL, Yuen KY, Seto WH. The Effects of Temperature and Relative Humidity on the Viability of the SARS Coronavirus. Advances in virology. 2011;2011:734690. PubMed PMID: 22312351. Pubmed Central PMCID: 3265313.

[7] Huang C, Wang Y, Li X, Ren L, Zhao J, $\mathrm{Hu} \mathrm{Y}$, et al. Clinical features of patients infected with 2019 novel coronavirus in Wuhan, China. Lancet. 2020 Feb 15;395(10223):497-506. PubMed PMID: 31986264. Pubmed Central PMCID: 7159299.

[8] Lu X, Zhang L, Du H, Zhang J, Li YY, $\mathrm{Qu} J$, et al. SARS-CoV-2 Infection in Children. The New England journal of medicine. 2020 Apr 23;382(17):1663-5. PubMed PMID: 32187458. Pubmed Central PMCID: 7121177.

[9] Rahman MA, Zaman N, Asyhari AT, AlTurjman F, Alam Bhuiyan MZ, Zolkipli MF. Data-driven dynamic clustering framework for mitigating the adverse economic impact of Covid-19 lockdown practices. Sustainable cities and society. 2020 Nov;62:102372. PubMed PMID: 32834935. Pubmed Central PMCID: 7333601.

[10] Pan F, Zheng C, Ye T, Li L, Liu D, Li L, et al. Different computed tomography patterns of Coronavirus Disease 2019 (COVID-19) between survivors and nonsurvivors. Scientific reports. 2020 Jul 
9;10(1):11336. PubMed PMID: 32647307. Pubmed Central PMCID: 7347874.

[11] Lai CC, Liu YH, Wang CY, Wang YH, Hsueh SC, Yen MY, et al. Asymptomatic carrier state, acute respiratory disease, and pneumonia due to severe acute respiratory syndrome coronavirus 2 (SARS-CoV-2): Facts and myths. Journal of microbiology, immunology, and infection $=$ Wei mian yu gan ran za zhi. 2020 Jun;53(3):404-12. PubMed PMID: 32173241. Pubmed Central PMCID: 7128959.

[12]Sun J, He WT, Wang L, Lai A, Ji X, Zhai $\mathrm{X}$, et al. COVID-19: Epidemiology, Evolution, and Cross-Disciplinary Perspectives. Trends in molecular medicine. 2020 May;26(5):483-95. PubMed PMID: 32359479. Pubmed Central PMCID: 7118693.

[13] Epidemiology Working Group for Ncip Epidemic Response CCfDC, Prevention. [The epidemiological characteristics of an outbreak of 2019 novel coronavirus diseases (COVID-19) in China]. Zhonghua liu xing bing xue za $\mathrm{zhi}=$ Zhonghua liuxingbingxue zazhi. 2020 Feb 10;41(2):145-51. PubMed PMID: 32064853.

[14]Mueller AL, McNamara MS, Sinclair DA. Why does COVID-19 disproportionately affect older people? Aging. 2020 May 29;12(10):9959-81. PubMed PMID: 32470948. Pubmed Central PMCID: 7288963.

[15]Leung JM, Sin DD. Smoking, ACE-2 and COVID-19: ongoing controversies. The European respiratory journal. $2020 \mathrm{Jul} ; 56(1)$. PubMed PMID: 32430431. Pubmed Central PMCID: 7363948 D.D. Sin reports grants from Merck, personal fees for advisory board work from Sanofi-Aventis and Regeneron, grants and personal fees for research from Boehringer Ingelheim, grants and personal fees for lectures and advisory board work from AstraZeneca, personal fees for lectures and advisory board work from Novartis, outside the submitted work.

[16]Wise J. Covid-19: Risk of second wave is very real, say researchers. Bmj. 2020 Jun 9;369:m2294. PubMed PMID: 32518177. [17] Xu S, Li Y. Beware of the second wave of COVID-19. Lancet. 2020 Apr 25;395(10233):1321-2. PubMed PMID: 32277876. Pubmed Central PMCID: 7194658 .

[18] Newbold SC, Finnoff D, Thunstrom L, Ashworth M, Shogren JF. Effects of Physical Distancing to Control COVID-19 on Public Health, the Economy, and the Environment. Environmental \& resource economics. 2020 Aug 4:1-25. PubMed PMID: 32836854. Pubmed Central PMCID: 7399603.

[19] Leung K, Wu JT, Liu D, Leung GM. First-wave COVID-19 transmissibility and severity in China outside Hubei after control measures, and second-wave scenario planning: a modelling impact assessment. Lancet. 2020 Apr 25;395(10233):1382-93. PubMed PMID: 32277878. Pubmed Central PMCID: 7195331.

[20]Delamater PL, Street EJ, Leslie TF, Yang YT, Jacobsen KH. Complexity of the Basic Reproduction Number (R0). Emerging infectious diseases. 2019 Jan;25(1):1-4. PubMed PMID: 30560777. Pubmed Central PMCID: 6302597.

[21]Balmford B, Annan JD, Hargreaves JC, Altoe M, Bateman IJ. Cross-Country Comparisons of Covid-19: Policy, Politics and the Price of Life. Environmental \& resource economics. 2020 Aug 4:1-27. 
PubMed PMID: 32836862. Pubmed Central PMCID: 7400753.

[22] Wu Y, Jing W, Liu J, Ma Q, Yuan J, Wang $Y$, et al. Effects of temperature and humidity on the daily new cases and new deaths of COVID-19 in 166 countries. The Science of the total environment. 2020 Aug 10;729:139051. PubMed PMID: 32361460. Pubmed Central PMCID: 7187824.

[23] Allocati N, Petrucci AG, Di Giovanni P, Masulli M, Di Ilio C, De Laurenzi V. Batman disease transmission: zoonotic pathogens from wildlife reservoirs to human populations. Cell death discovery. 2016;2:16048. PubMed PMID: 27551536. Pubmed Central PMCID: 4979447.

[24]Paynter S. Humidity and respiratory virus transmission in tropical and temperate settings. Epidemiology and infection. 2015 Apr;143(6):1110-8. PubMed PMID: 25307020.

[25] Peci A, Winter AL, Li Y, Gnaneshan S, Liu J, Mubareka S, et al. Effects of Absolute Humidity, Relative Humidity, Temperature, and Wind Speed on Influenza Activity in Toronto, Ontario, Canada. Applied and environmental microbiology. 2019 Mar 15;85(6). PubMed PMID: 30610079. Pubmed Central PMCID: 6414376.

[26]Marr LC, Tang JW, Van Mullekom J, Lakdawala SS. Mechanistic insights into the effect of humidity on airborne influenza virus survival, transmission and incidence. Journal of the Royal Society, Interface. 2019 Jan 31;16(150):20180298. PubMed PMID: 30958176. Pubmed Central PMCID: 6364647.

[27] Sahin M. Impact of weather on COVID19 pandemic in Turkey. The Science of the total environment. 2020 Aug 1;728:138810.
PubMed PMID: 32334158. Pubmed Central PMCID: 7169889. 